Article

\title{
Synthesis, Crystal Structures and Characterization of Two Nonmetal Cation Tetrafluoroborates
}

\author{
Noura Othman Alzamil ${ }^{1}$, Ghareeba Mussad Al-Enzi ${ }^{1}$, Aishah Hassan Alamri ${ }^{1}$, Insaf Abdi ${ }^{2}$ \\ and Amor BenAli 1,3,* \\ 1 Department of Chemistry, College of Science, Imam Abdulrahman Bin Faisal University, P.O. Box 1982, \\ Dammam 31441, Saudi Arabia; nalzamil@iau.edu.sa (N.O.A.); gmalenzi@iau.edu.sa (G.M.A.-E.); \\ ahalamri@iau.edu.sa (A.H.A.) \\ 2 Department of Basic Sciences, Chemistry unit, Deanship of preparatory year and supporting studies, \\ Imam Abdulrahman Bin Faisal University. P.O. Box 1982, Dammam 34212, Saudi Arabia; iaabdi@iau.edu.sa \\ 3 Basic and Applied Scientific Research Center, Imam Abdulrahman Bin Faisal University, P.O. Box 1982, \\ Dammam 31441, Saudi Arabia \\ * Correspondence: asbali@iau.edu.sa
}

Received: 28 August 2020; Accepted: 10 September 2020; Published: 14 September 2020

\begin{abstract}
Two new nonmetal cation tetrafluoroborate phases $\left[\mathrm{H}_{3}\right.$ tren $]\left(\mathrm{BF}_{4}\right)_{3}(\mathrm{I})$ and $\left[\mathrm{H}_{3}\right.$ tren $]\left(\mathrm{BF}_{4}\right)_{3}$ HF (II) were synthesized by microwave-assisted solvothermal and characterized by single crystal X-ray diffraction, IR spectroscopy and thermal analysis DTA-TGA. $\left[\mathrm{H}_{3}\right.$ tren $]\left(\mathrm{BF}_{4}\right)_{3}$ is cubic $\left(\boldsymbol{P 2} \mathbf{2}_{1} 3\right)$ with unit cell parameter $\boldsymbol{a}=11.688(1) \AA$. $\left[\mathrm{H}_{3}\right.$ tren $]\left(\mathrm{BF}_{4}\right)_{3} \bullet \mathrm{HF}$ is trigonal $(\boldsymbol{R} 3 \boldsymbol{c})$ with unit cell parameters $a=15.297(6) \AA$ and $c=12.007(2) \AA$. Both (I) and (II) structures can be described from isolated tetrafluoroborate $\mathrm{BF}_{4}{ }^{-}$anions, triprotonated tris-(2-aminoethyl)amine (tren) $\left[\mathrm{H}_{3} \text { tren }\right]^{3+}$. Phase (II) contains disordered $\mathrm{BF}_{4}{ }^{-}$tetrahedron and hydrofluoric acid.
\end{abstract}

Keywords: tetrafluoroborate; solvothermal; crystal structure; IR spectroscopy

\section{Introduction}

Hybrid materials are chemical compounds consisting of the association of organic moiety and inorganic portion. The inorganic part generally comprises of metal or nonmetal cations surrounded by electron donor atoms such as nitrogen, oxygen, fluorine, etc. Organic molecules are highly diverse and may contain functions such as carboxylates, phosphonates and amines. The idea behind this type of material is to couple specific properties of the various components within a single entity. The assembly of the properties of both components can be established in two ways: first, the entity simply presents the final properties of the two components regarding simple apposition, or second, the combination of two properties induces a strong synergistic interaction, allowing the creation of a new property resulting from the association of specific physical properties, such as optical, mechanical, magnetic and/or electrical properties.

Hybrid materials can be classified according to the dimensionality of the network. The dimensionality of the network can be 0D formed by isolated polyanions [1], one dimensional (1D) chains [2], two-dimensional (2D) formed by layers [3,4], and three-dimensional (3D) [5]. The cohesion between organic and inorganic moieties are provided by weak forces (hydrogen bonding and Van der Waals forces) or strong forces (covalent bonds).

Hybrid materials have applications in various domains such as gas molecule storage: $\mathrm{CO}_{2}$ for its conversion ability [6], $\mathrm{H}_{2}$ for fuel cells that provide a solution to the energy crisis [7], catalysis [8], and petroleum cracking [9]. Other applications related to the physical properties of these materials are possible in the field of Non-Linear Optical (NLO) [10,11], luminescence [12] or ferroelectricity [13]. 
Nonmetal cation oxoborates or tetrafluoroborates can be considered as a branch of hybrid solid in which the inorganic moiety does not contain metals. Nonmetal cation borates have received considerable attention due to their structural architecture which make them candidates to interesting applications in many domains such a: catalysis [14,15], ion exchange [16,17], Non-Linear Optical (NLO) [18] etc. Recently, H.-X. Liu et al. [19] reported nonmetal borates $\left[\mathrm{C}_{6} \mathrm{H}_{13} \mathrm{~N}_{2}\right]\left[\mathrm{B}_{5} \mathrm{O}_{6}(\mathrm{OH})_{4}\right]$ with interesting NLO properties. This compound presents a Second Harmonic Generation (SHG) efficiency nearly 0.9 times that of standard potassium dehydrogenates phosphate (KDP). V. Gieu et al. [20] and J. Ramajouti et al. [21] reported examples of tetrafluoroborates showing motivating NLO properties. In addition to their optical properties, nonmetal cation tetrafluoroborates are largely used as friendly solvent ionic liquids [22-24]. These ionic liquids are widely used for applications in separation, selective adsorption performed under humid conditions or catalysis in water. Great efforts are given to the synthesis and the crystal structure study of these materials since their physical properties are strongly dependent to their structures.

In this paper, we describe the solvothermal synthesis, single crystal X-ray measurements, thermal behaviour and IR spectroscopy of two nonmetal cation tetrafluoroborates $\left[\mathrm{H}_{3}\right.$ tren $]\left(\mathrm{BF}_{4}\right)_{3}$ (I) and $\left[\mathrm{H}_{3}\right.$ tren $]\left(\mathrm{BF}_{4}\right)_{3} \mathrm{HF}$ (II).

\section{Materials and Methods}

\subsection{Synthesis of $\left[\mathrm{H}_{3}\right.$ tren $]\left(\mathrm{BF}_{4}\right)_{3}$ (I) and $\left[\mathrm{H}_{3}\right.$ tren $]\left(\mathrm{BF}_{4}\right)_{3} \bullet \mathrm{HF}$ (II)}

$\left[\mathrm{H}_{3}\right.$ tren $]\left(\mathrm{BF}_{4}\right)_{3}$ (I) and $\left[\mathrm{H}_{3}\right.$ tren $]\left(\mathrm{BF}_{4}\right)_{3} \mathrm{HF}$ (II) were synthesized by the hydrothermal synthesis method using microwave heating (oven MDS2100). Mixture of $0.5 \mathrm{~g}\left(8.1 \mathrm{mmol}\right.$ ) of boric acid $\mathrm{B}(\mathrm{OH})_{3}$, $1.3 \mathrm{~mL}(8.1 \mathrm{mmol})$ of tris-(2-aminoethyl)amine (tren) $(95 \%)$ were dissolved in $10 \mathrm{~mL}$ of ethanol and introduced in Teflon vessel. Hydrofluoric acid HF (40\%, Riedel-de Haën) was then added: $0.71 \mathrm{~mL}$ for phase (I) and $3.55 \mathrm{~mL}$ for phase (II). The mixture is heated at $190^{\circ} \mathrm{C}$ for $1 \mathrm{~h}$. Crystals of (I) and (II) can be obtained with high crystallinity using Teflon lined PARR autoclaves at $190^{\circ} \mathrm{C}$ for $48 \mathrm{~h}$.

\subsection{Single-Crystal Data Collection and Structure Determination}

Single crystal X-ray diffraction data were obtained on a SIEMENS AED2 four-circle diffractometer at room temperature using $\omega-2 \theta$ scans. The structure determinations were carried out with SHELXS-97 [25], SHELXL-97 [26] programs within the WINGX package [27]. Positions and anisotropic displacement parameters for all non-hydrogen atoms are freely refined without any constraints. Hydrogen atoms bound to carbon and nitrogen atoms are fixed geometrically using AFIX23 and AFIX137 for $\mathrm{CH}_{2}$ and $\mathrm{CH}_{3}$ groups, respectively. Experimental powder X-ray diffraction patterns of the two compounds are in good agreement with those calculated using full pattern matching mode simulations (Figure S2 for (I) and S5 for (II) in the ESI).

\subsubsection{Structure Determination of $\left[\mathrm{H}_{3}\right.$ tren $]\left(\mathrm{BF}_{4}\right)_{3}(\mathrm{I})$}

The extinction conditions have led to the $\boldsymbol{P 2} \mathbf{2}_{1} 3$ non-centrosymetric space group. The structure of $\left[\mathrm{H}_{3}\right.$ tren $]\left(\mathrm{BF}_{4}\right)_{3}$ was solved by the TREF option in SHELXS-97 program. Three boron and two fluorine atoms were first located at $4 a$ crystallographic sites. The remaining non-hydrogen atoms: fluorine, nitrogen and carbon were localized from Fourier difference map and were distinguished from distance criteria [28]. Three primary amines of tren molecule are found to be protonated unlike tertiary amine. Final refinements of atomic positions, anisotropic displacement parameters (ADP) and secondary extinction converged to $\mathrm{R}=0.062$ and $\mathrm{R}_{\mathrm{W}}=0.190$ (1241 independent reflections and 79 parameters).

\subsubsection{Structure Determination of $\left[\mathrm{H}_{3}\right.$ tren $]\left(\mathrm{BF}_{4}\right)_{3} \mathrm{HF}$ (II)}

All attempts to solve the structure in the centrosymmetric space group (R-3c) have been unsuccessful. The agreement factors are high, and no acceptable structural model has been proposed. This prompted us to determine the structure in the non-centrosymmetric space groupR3c. TREF option 
in SHELXS-97 program was used to get the preliminary solution. The five atoms found were attributed arbitrarily to carbon atoms. The visualization of the arrangement of these atoms, using the Cameron graphic tool included in the Wingx package, helps to distinguish between carbon, nitrogen and fluorine atoms. At this step, all the atoms were located in general position except $\mathrm{N}(1)$ in special crystallographic site $6 \mathrm{a}$. The remaining fluorine, boron and carbon atoms were localized from Fourier difference maps and were distinguished from distance criteria. Unbounded fluorine atoms are attributed to hydrofluoric acid. The hydrogen atom is easily located using the difference Fourier map.

The atomic displacement parameters of the fluorine atoms $F(2)$ and $F(4)$ were found to be abnormally high. These two fluorine atoms are disordered, and hence each atom is equitably positioned in two general positions with an occupation factor equal to $50 \%$. Similarly to phase (I), the three primary amines of tren molecule are found to be protonated, unlike tertiary amine. The refinement of all atomic positions and anisotropic atomic displacement parameters (ADP) for all atoms except hydrogen atoms leads to confidence factors $R_{1}=0.07$ and $R w=0.21$ (825 independent reflections and 99 parameters).

The conditions of data collection for both phases are shown in Table 1.

Table 1. Crystallographic data of $\left[\mathrm{H}_{3}\right.$ tren $]\left(\mathrm{BF}_{4}\right)_{3}$ (I) and $\left[\mathrm{H}_{3}\right.$ tren $]\left(\mathrm{BF}_{4}\right)_{3} \mathrm{HF}$ (II).

\begin{tabular}{|c|c|c|}
\hline & $\mathbf{I}$ & II \\
\hline Formula & $\mathrm{B}_{3} \mathrm{~F}_{12} \mathrm{~N}_{4} \mathrm{C}_{6} \mathrm{H}_{21}$ & $\mathrm{~B}_{3} \mathrm{~F}_{13} \mathrm{~N}_{4} \mathrm{C}_{6} \mathrm{H}_{22}$ \\
\hline Formula weight $\left(\mathrm{g} \mathrm{mol}^{-1}\right)$ & 409.7 & 429.7 \\
\hline Crystal system & cubic & trigonal \\
\hline Space group & $\mathrm{P} 2{ }_{1} 3\left(\mathrm{n}^{\circ} 198\right)$ & $R 3 c\left(n^{\circ} 161\right)$ \\
\hline $\mathrm{a}(\AA \stackrel{\circ}{)}$ & 11.688(1) & 15.297(6) \\
\hline$b(\AA)$ & $11.688(1)$ & $15.297(6)$ \\
\hline c $(\AA)$ & $11.688(1)$ & $12.0070(2)$ \\
\hline $\mathrm{V}\left(\AA^{3}\right), \mathrm{Z}$ & $1596.7(4) ; 4$ & $2433.2(4) ; 6$ \\
\hline Wavelength $(\mathrm{MoK} \alpha)(\AA)$ & & 0.71073 \\
\hline Dimensions $\left(\mathrm{mm}^{3}\right)$ & $0.095 \times 0.209 \times 0.190$ & $0.08 \times 0.13 \times 0.61$ \\
\hline$\mu(\mathrm{MoK} \alpha)\left(\mathrm{mm}^{-1}\right)$ & 0.2 & 0.2 \\
\hline$\rho_{\text {calc. }}\left(\mathrm{g} \mathrm{cm}^{-3}\right)$ & 1.704 & 1.682 \\
\hline Temperature (K) & & 298 \\
\hline $2 \theta$ range $\left(^{\circ}\right)$ & 3-55 & 3-60 \\
\hline (hkl) limits (one unique set) & $\begin{array}{c}-10 \leq \mathrm{h} \leq 10 \\
-10 \leq \mathrm{k} \leq 10 \\
-15 \leq l \leq 15\end{array}$ & $\begin{array}{c}-21 \leq \mathrm{h} \leq 10 \\
0 \leq \mathrm{k} \leq 21 \\
0 \leq l \leq 16\end{array}$ \\
\hline Scan mode & & $\omega-2 \theta$ \\
\hline Reflexions measured/unique/(I $>2 \sigma(\mathrm{I}))$ & $1430 / 1241 / 893$ & $1581 / 825 / 748$ \\
\hline $\mathrm{R}($ int $) / \mathrm{R}($ sigma $)$ & $0.0175 / 0.003$ & $0.0152 / 0.0127$ \\
\hline Number of refined parameters (on $\mathrm{F}^{2}$ ) & 79 & 99 \\
\hline${ }^{a} R / R_{w}$ & $0.062 / 0.190$ & $0.070 / 0.212$ \\
\hline Goodness of fit & 1.089 & 0.994 \\
\hline Difference Fourier residues $\left(\mathrm{e} \AA^{-3}\right)$ & $0.56 /-0.27$ & $0.47 /-0.36$ \\
\hline
\end{tabular}

\section{Results}

\subsection{Structure Description of $\left[\mathrm{H}_{3}\right.$ tren $]\left(\mathrm{BF}_{4}\right)_{3}(\mathrm{I})$}

The asymmetric unit of $\left[\mathrm{H}_{3}\right.$ tren $]\left(\mathrm{BF}_{4}\right)_{3}$, drawn using the ORTEP program [29], contains three independent boron atoms, six fluorine anion, two nitrogen atoms, and two carbon atoms. Ellipsoids are given with a probability of $50 \%$ and show an abnormally high thermal agitation for some fluorine atoms (Figure S1, left in the Supplementary).

The structure of $\left[\mathrm{H}_{3}\right.$ tren $]\left(\mathrm{BF}_{4}\right)_{3}$ can be described as a distorted $\mathrm{BF}_{4}$ tetrahedron and $\left[\mathrm{H}_{3} \text { tren }\right]^{3+}$ triprotonated amine (Figure 1). In each $\mathrm{BF}_{4}{ }^{-}$tetrahedron, the boron atom is linked to three equivalent fluorine atoms and one other fluorine atom. The average of the distances $\mathrm{B}(1)-\mathrm{F}$ and $\mathrm{B}(2)-\mathrm{F}$ are strictly identical and are equal to $1.37 \AA$, while the mean B(3)-F distance is $1.34 \AA$. In each tetrahedron, two F-B-F angles are observed, ranging from 107 to $111^{\circ}$ with an average of $109.5^{\circ}$. These two angles are close to being the same for the $\mathrm{B}(2) \mathrm{F}_{4}$ tetrahedron. The values of F-B-F angles and B-F distances in phase (I) are 
comparable to those found in other nonmetal cation tetrafluoroborates encountered in the literature. The $\mathrm{N}-\mathrm{C}$ distances are slightly smaller than the $\mathrm{C}-\mathrm{C}$ distances in the organic part. These interatomic distances and angles are habitually observed in hybrid compounds.

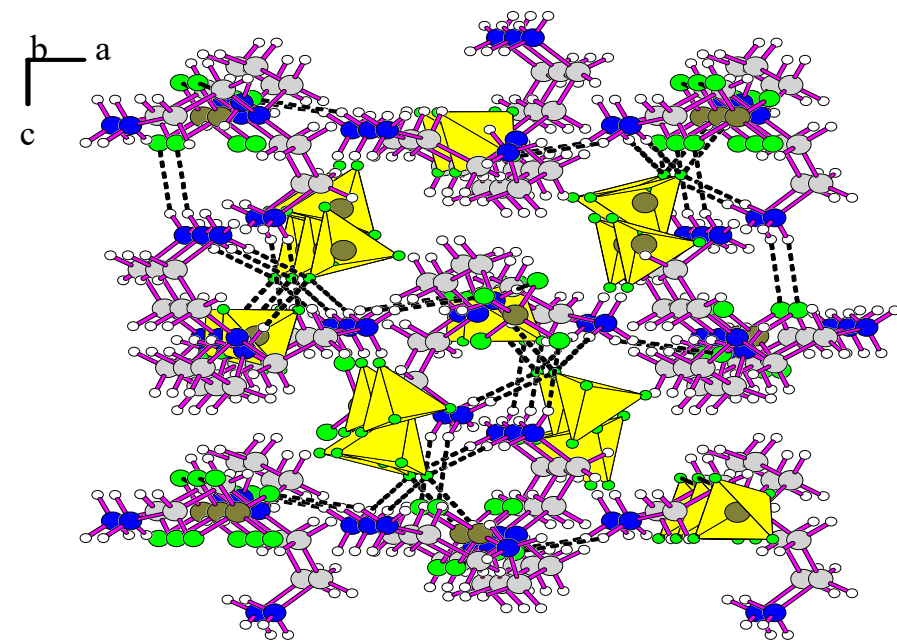

Figure 1. View of the structure of $\left[\mathrm{H}_{3}\right.$ tren $]\left(\mathrm{BF}_{4}\right)_{3}$.

Strong hydrogen bonds are established between fluorine atoms of $\mathrm{B}(1) \mathrm{F}_{4}$ and $\mathrm{B}(2) \mathrm{F}_{4}$ with hydrogen atoms of terminal nitrogen atoms of the organic molecule and form 3 dimensional network. One can note that $\mathrm{B}(3) \mathrm{F}_{4}$ is free, and that no hydrogen bonds exist between fluorine atoms and hydrogen atoms of terminal amine groups.

The terminal $\mathrm{N}(2) \mathrm{H}_{3}$ groups established hydrogen bonds $\left(\mathrm{d}_{\mathrm{N}-\mathrm{F}}<2.94 \AA\right)$ with fluoride ligands, whereas central nitrogen $N_{c}$ atoms are distant from fluoride anions $(d>3.03 \AA)$. The three equivalent fluorine atoms $\mathrm{F}(4)$ of the $\mathrm{B}(2) \mathrm{F}_{4}$ tetrahedron link three amine groups $\left[\mathrm{H}_{3} \text { tren }\right]^{3+}$. Fluorine ion $\mathrm{F}(1)$ of the $\mathrm{B}(1) \mathrm{F}_{4}$ tetrahedron established three hydrogen bonds with three hydrogen atoms of the three terminal atoms of the same triprotonated amine molecule (Figure 2). The $\left[\mathrm{H}_{3} \text { tren }\right]^{3+}$ cation adopts a "spider"-shaped configuration. It should be considered that tren amines cannot be tetra protonated, as proved from the values of the $\mathrm{N}_{\mathrm{c}}-\mathrm{N}_{t}$ distances from central nitrogen atoms $\mathrm{N}_{\mathrm{c}}$ to terminal nitrogen atoms $\mathrm{N}_{\mathrm{t}}$ [30-32], and $\mathrm{N}_{\mathrm{t}}-\mathrm{N}_{\mathrm{t}}$ distances. Only the scorpion configuration corresponds to a tetra protonated amine (Figure 3).

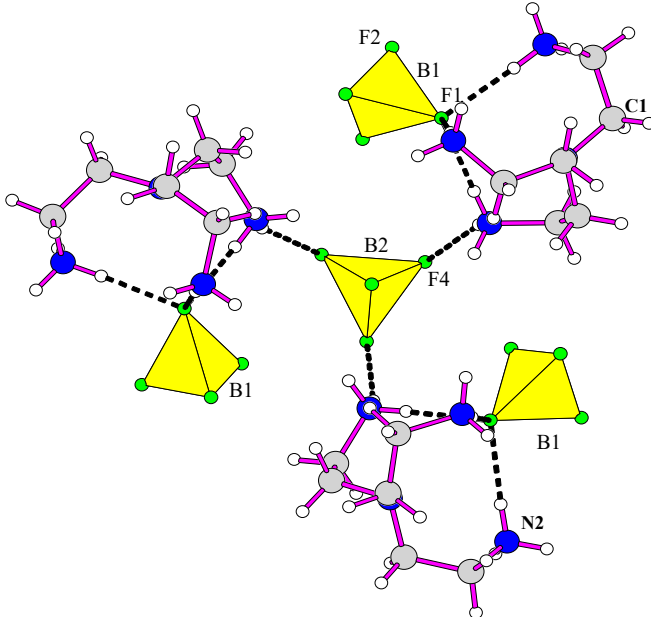

Figure 2. Environment of the $\mathrm{BF}_{4}$ tetrahedron and $\left[\mathrm{H}_{3}\right.$ tren $]$ cation in the structure of $\left[\mathrm{H}_{3}\right.$ tren $]\left(\mathrm{BF}_{4}\right)_{3}$. 


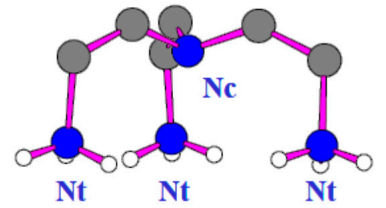

$\mathrm{Nc}-\mathrm{Nt} \approx 3 \cdot 0-3.3 \AA$

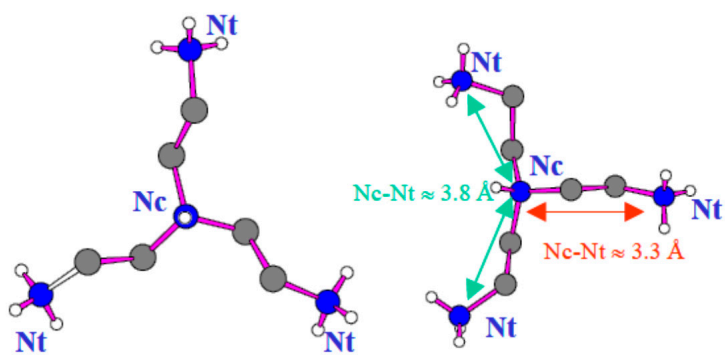

$\mathrm{Nc}-\mathrm{Nt} \approx 3.8 \AA$

Figure 3. Configuration spider (left), plane (middle) and scorpion (right) of the tren amine.

\subsection{Structure Description of $\left[\mathrm{H}_{3} \operatorname{tren}\right]\left(\mathrm{BF}_{4}\right)_{3} \mathrm{HF}$ (II)}

The projection of the structure along the $c$ direction is given in Figure 4 . The asymmetric unit of the structure of $\left[\mathrm{H}_{3}\right.$ tren $]\left(\mathrm{BF}_{4}\right)_{3} \mathrm{HF}$ is composed of ethylene diamine groups and distorted $\mathrm{BF}_{4}{ }^{-}$tetrahedron anions. One can see that the disordered fluorine atoms have high atomic displacement parameters. Atomic displacement parameters of terminal nitrogen atoms are almost greater than tertiary amine group (Figure S1, right in the Supplementary).

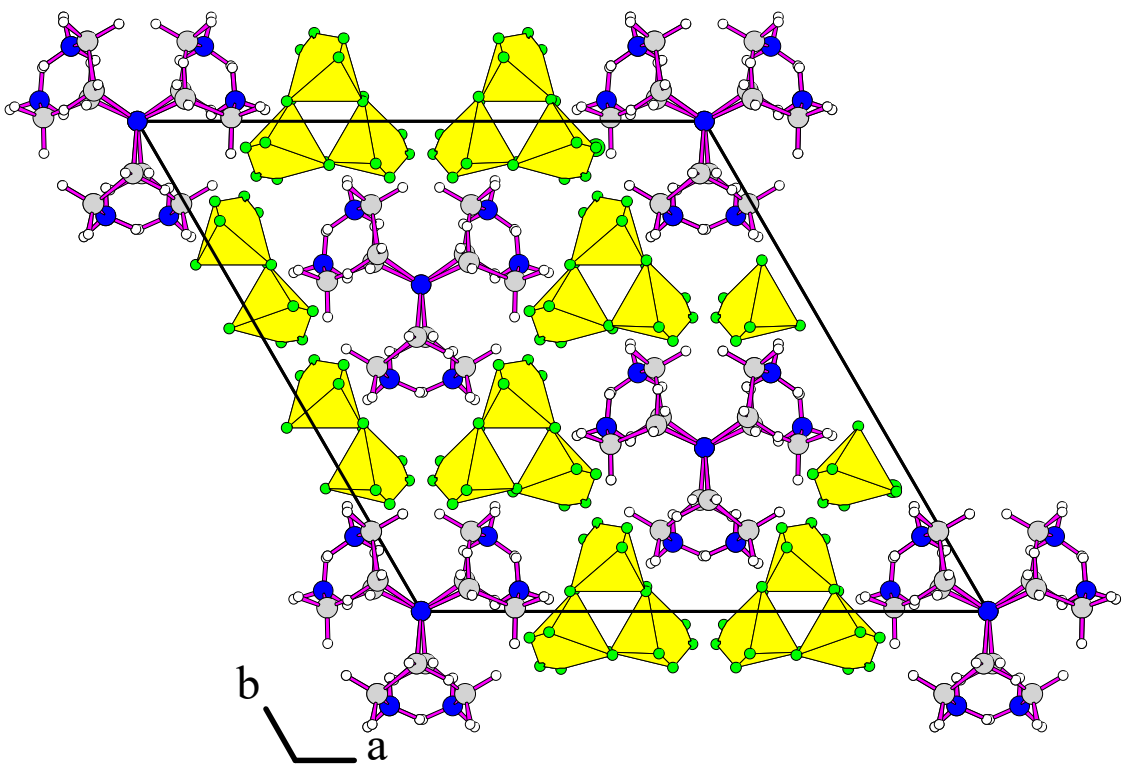

Figure 4. Projection of the structure of $\left[\mathrm{H}_{3}\right.$ tren $]\left(\mathrm{BF}_{4}\right)_{3} \mathrm{HF}$ along the [001] direction.

In the structure of $\left[\mathrm{H}_{3}\right.$ tren $]\left(\mathrm{BF}_{4}\right)_{3} \mathrm{HF}$, the environment of boron is disordered. It is composed of four fluorine atoms; among them, two occupy a general position with a $50 \%$ occupancy factor. The distances B-F vary between 1.29 and $1.44 \AA$, with an average of $1.36 \AA$. Distances between disordered fluorine atoms are 0.76(3) and 0.77(2) for $F(2)-F(2) p$ and $F(4)-F(4) p$, respectively. Distances between two non-equivalent fluorine atoms vary between 2.17 and $2.3 \AA$.

Hydrogen bonds are established between fluorine atoms of hydrofluoric acid and three hydrogen atoms, each one belongs to one terminal $\mathrm{NH}_{3}$ groups of the one organic molecules (Figure 5). In addition, each of the organic molecules established via $\mathrm{NH}_{3}$ groups hydrogen bonds with $\mathrm{F}(2), \mathrm{F}(3)$ and $\mathrm{F}$. A total of 15 hydrogen bonds are observed between organic molecules and inorganic part. 


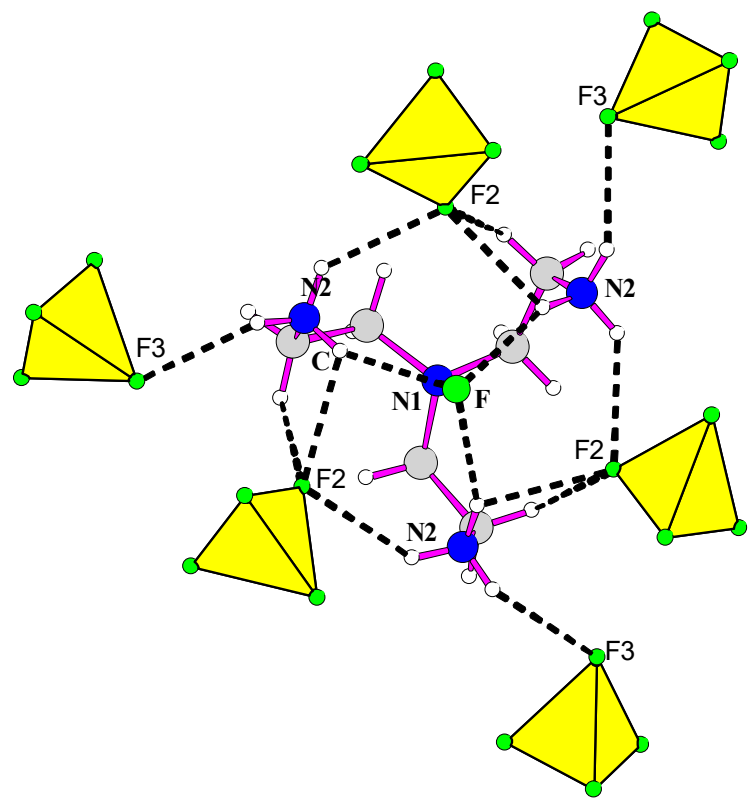

Figure 5. Hydrogen bonds in $\left[\mathrm{H}_{3}\right.$ tren $]\left(\mathrm{BF}_{4}\right)_{3} \mathrm{HF}$.

Concerning the organic moiety, the amine is triproptonated $\left[\mathrm{H}_{3} \text { tren }\right]^{3+}$ and adopts a "spider" type configuration. Indeed, the values of the $\mathrm{N}_{\mathrm{c}}-\mathrm{N}_{\mathrm{t}}$ distances from central nitrogen atoms $\mathrm{N}_{\mathrm{c}}$ to terminal nitrogen atoms $\mathrm{N}_{\mathrm{t}}(3.147 \AA)$, as well as $\mathrm{N}_{\mathrm{t}}-\mathrm{N}_{\mathrm{t}}$ distances $(4.67 \AA)$, agree with triprotonated amine. The averages of the $\mathrm{N}-\mathrm{C}$ distances $(1.496 \AA)$ and the $\mathrm{C}-\mathrm{C}$ distances $(1.517 \AA)$ are similar to those encountered in other hybrid compounds.

\subsection{Thermal Analysis}

Thermal behavior DTA-TGA was studied using a TA 2960 instrument within a temperature range $25-650{ }^{\circ} \mathrm{C}$ with heating rate $10^{\circ} \mathrm{C} / \mathrm{min}$ in an argon atmosphere (Figures S3 and S6 in the Supplementary). Upon heating, $\left[\mathrm{H}_{3}\right.$ tren $] \cdot\left(\mathrm{BF}_{4}\right)_{3}$ exhibited a single weight loss which took place in the interval $200-450{ }^{\circ} \mathrm{C}$, and was attributed to the loss of almost the totality of the sample. This weight loss corresponds to the decomposition of the organic molecules and the departure of $\mathrm{BF}_{3}$. Less than $10 \%$ of the residual sample was attributed to black carbon. For $\left[\mathrm{H}_{3}\right.$ tren $]\left(\mathrm{BF}_{4}\right)_{3} \mathrm{HF}$ (II), two weight losses were observed in two steps; the first step was observed in the interval $100-250{ }^{\circ} \mathrm{C}$, and was assigned to the loss of one mole of HF molecules per one mole of (II) (exp./th. = 4.83/4.87) for (II). The second weight loss, which occurred in the interval $250-425^{\circ} \mathrm{C}$, corresponded to the decomposition of the organic molecules and the departure of $\mathrm{BF}_{3}$.

\subsection{IR Spectroscopy}

Infrared spectroscopy is effectively used to approve the structure determined by X-ray diffraction and to identify functional groups in the obtained material. To qualitatively analyze the main functional groups in these compounds, the infrared spectrum was acquired using a Bomem Michelson MB120 Fourier transform infrared spectrometer with a diamond-anvil cell as a micro sampling device. Infrared data were collected in the range $650-4000 \mathrm{~cm}^{-1}$. Spectral resolution was $4 \mathrm{~cm}^{-1}$.

The infrared spectrum of compounds (I), (II) and tris-(2-aminoethyl)amine are given in the Electronic Supplementary Information ESI (Figures S4, S7 and S8). Infrared spectra of (I) and (II) are quite similar. Absorption peaks at higher wave numbers $\left(3300-3150 \mathrm{~cm}^{-1}\right)$ for (I) and (II) are assigned to $\mathrm{N}-\mathrm{H}$ symmetric and antisymmetric stretching vibrations of $\mathrm{NH}_{3}$ groups. A clear shift to higher wavenumbers is observed compared to the starting reactant tris-(2-aminoethyl)amine. This shift is attributed to the presence of strong hydrogen bonding N-H.F in (I) and (II). Moreover, hydrogen bonds are stronger in (II) compared to (I), in direct correlation with N-F distances (Tables S3 and S6 
in the Supplementary). This may explain the appearance of $v\left(\mathrm{NH}_{3}\right)$ at higher wavenumber in (II). Bands observed in the range $2850-2930 \mathrm{~cm}^{-1}$ are assigned to symmetric and antisymmetric stretching of methylene groups. For example, in compound (I), methylene scissoring, wagging, twisting and rocking vibration bands appear, respectively, around 1469, 1323, 1298 and $724 \mathrm{~cm}^{-1}$. C-N and C-C aliphatic groups stretching bands are observed in the range $1220-1020 \mathrm{~cm}^{-1}$ [33]. These results are in good agreement with the literature [34,35].

Tetrafluoroborate anion $\mathrm{BF}_{4}{ }^{-}$is characterized by both symmetric and asymmetric stretching and deformation vibrations. For ideal $\mathrm{BF}_{4}$ tetrahedron, symmetric modes $v_{1}$ (symmetric stretching) $=777 \mathrm{~cm}^{-1}$ and $v_{2}$ (symmetric deformation) $=360 \mathrm{~cm}^{-1}$ are Raman active whereas $v_{3}$ (asymmetric stretching) $=1070 \mathrm{~cm}^{-1}$ and $v_{4}$ (asymmetric deformation) $=533 \mathrm{~cm}^{-1}$ are both Raman and IR active [36]. One can note that $v_{1}$ (symmetric stretching) appear in both IR spectra of (I) and (II) in spite that this mode is IR inactive for regular $\mathrm{BF}_{4}$ tetrahedron [37]. Broadening of peaks corresponding to $\mathrm{BF}_{4}$ tetrahedron in phase (II) compared to phase (I) may explain the disordered observed for two fluorine atoms belonging to boron atoms. An approximately full assignment of band vibrations is given in Tables S7 and S8 in the Supplementary.

For compound (II), no vibration bands corresponding to $\mathrm{H}_{2} \mathrm{O}$ are observed, this supports the results obtained by $\mathrm{X}$-ray diffraction and agrees with the thermogravimetric analysis. On the other hand, the formula of (II) with hydrofluoric acid is in good agreement with synthesis condition in high HF ratio.

\section{Conclusions}

In the chemical system boric acid tris-(2-aminoethyl) amine (tren)-hydrofluoric acid, two new phases were successfully obtained, and their structures were determined by single-crystal X-ray diffraction method. These two obtained phases were characterized by means of various techniques, such as single-crystal and powder X-ray diffraction, IR absorption spectroscopy, and thermal analysis.

The cubic structure of $\left[\mathrm{H}_{3}\right.$ tren $]\left(\mathrm{BF}_{4}\right)_{3}$ (I) can be described as a distorted $\mathrm{BF}_{4}$ tetrahedron and organic cations $\left[\mathrm{H}_{3} \text { tren }\right]^{3+}$. The cohesion between the two entities is provided by strong hydrogen bonds. In the structure of $\left[\mathrm{H}_{3}\right.$ tren $]\left(\mathrm{BF}_{4}\right)_{3} \mathrm{HF}$ (II) the $\mathrm{B}^{3+}$ cations environment is disordered: two fluorine atoms of $\mathrm{BF}_{4}$ tetrahedron occupy two positions with occupancy factor of $50 \%$. Compared with previous studies, the amine tren is triprotonated $\left[\mathrm{H}_{3} \text { tren }\right]^{3+}$ and adopts a spider configuration.

Borate materials, including nonmetal tetrafluoroborates, are candidates in practical applications mainly as second harmonic generating (SHG) optical materials, host materials for fluorescence, piezoelectric materials, and so on. These applications are related to the diversity in the structural architecture of this class of materials.

Supplementary Materials: CSD 2009817 and 2009720 contain the supplementary crystallographic data for (I) and (II) compounds respectively. These data can be obtained free of charge from The Cambridge Crystallographic Data Centre via www.ccdc.cam.ac.uk/data_request/cif.

Author Contributions: N.O.A. and G.M.A.-E. conceived and designed the experiments; I.A., A.H.A. and A.B. carried out the X-ray diffraction analysis; all authors planned the characterization by IR, absorption spectroscopy. All authors took part in writing and discussion processes. All authors have read and agreed to the published version of the manuscript.

Funding: This research received no external.

Acknowledgments: The authors would like to express their gratitude to Vincent Maisonneuve (Le Mans University, France), for X-ray data collection. This work received support from Grant 2020-084-BASRC awarded by the Research Center, Scientific Research Deanship, Imam Abdulrahman Bin Faisal University, KSA.

Conflicts of Interest: The authors declare no conflict of interest. 


\section{References}

1. Jayasundera, C.A.; Goff, R.J.; Li, J.; Lightfoot, P. Solvothermal indium fluoride chemistry: Syntheses and crystal structures of $\mathrm{K}_{5} \mathrm{In}_{3} \mathrm{~F}_{14}, \beta-\left(\mathrm{NH}_{4}\right)_{3} \mathrm{InF}_{6}$ and $\left[\mathrm{NH}_{4}\right]_{3}\left[\mathrm{C}_{6} \mathrm{H}_{21} \mathrm{~N}_{4}\right]_{2}\left[\mathrm{In}_{4} \mathrm{~F}_{21}\right]$. J. Solid State Chem. 2010, 183, 356. [CrossRef]

2. Adil, A.; Leblanc, M.; Maisonneuve, V.; Lightfoot, P. Structural chemistry of organically-templated metal fluorides. Dalton Trans. 2010, 39, 5983. [CrossRef] [PubMed]

3. Lhoste, J.; Rocquefelte, X.; Dessapt, R.; Jobic, S. A New Organic-Inorganic Hybrid Oxyfluorotitanate [Hgua $]_{2} \cdot\left(\mathrm{Ti}_{5} \mathrm{O}_{5} \mathrm{~F}_{12}\right)$ as a Transparent UV Filter. Inorg. Chem. 2011, 50, 5671. [CrossRef] [PubMed]

4. Abdi, I.; Lhoste, J.; Leblanc, M.; Maisonneuve, V.; Grenèche, J.-M.; Viau, G.; Ben Ali, A. [H $\mathrm{H}_{2}$ amtaz] ${ }^{+}$iron fluorides: Synthesis, crystal structures, magnetic and Mössbauer studies. J. Fluo. Chem. 2015, 173, 23. [CrossRef]

5. Cadiau, A.; Martineau, C.; Taulelle, F.; Adil, K. Investigation of the composition space diagram of the $\mathrm{ZnF}_{2}-3,5$-diamino-1,2,4-triazole-HF- $\mathrm{H}_{2} \mathrm{O}$ chemical system and structural characterization of a new fluorinated guanazolate MOF $\left[\mathrm{Zn}_{3} \mathrm{~F}_{2}\right] \cdot\left(\mathrm{Am}_{2} \mathrm{TAZ}\right)_{4}$. J. Fluorine Chem. 2013, 150, 104. [CrossRef]

6. Nijem, N.; Wu, H.H.; Canepa, P.; Marti, A. Tuning the Gate Opening Pressure of Metal-Organic Frameworks (MOFs) for the Selective Separation of Hydrocarbons. J. Am. Chem. Soc. 2012, 134, 15201. [CrossRef]

7. Benaouadj, M.; Aboubou, A.; Ayad, M.Y.; Becherif, M. Nonlinear Flatness Control Applied to Supercapacitors Contribution in Hybrid Power Systems Using Photovoltaic Source and Batteries. Energy Procedia 2014, 50, 333. [CrossRef]

8. Luz, I.; Corma, A.; Llabres, F.X. Cu-MOFs as active, selective and reusable catalysts for oxidative C-O bond coupling reactions by direct $\mathrm{C}-\mathrm{H}$ activation of formamides, aldehydes and ethers. Catal. Sci. Technol. 2014, 4, 1829. [CrossRef]

9. Horcajada, P.; Gref, R.; Baati, T.; Allan, P.K. Metal-Organic Frameworks in Biomedicine. Chem. Rev. 2012, 112, 1232. [CrossRef]

10. Espa, D.; Pilia, L.; Makedonas, C.; Marchio, L.; Mercuri, M.L. Role of the Acceptor in Tuning the Properties of Metal $[\mathrm{M}(\mathrm{II})=\mathrm{Ni}, \mathrm{Pd}, \mathrm{Pt}]$ Dithiolato/Dithione (Donor/Acceptor) Second-Order Nonlinear Chromophores: Combined Experimental and Theoretical Studies. Inorg. Chem. 2014, 53, 1170. [CrossRef]

11. Zidan, D.; Al-Ktaifani, M.M.; L-Daher, M.S.E.; Allahham, A.; Ghanem, A. Diffraction ring patterns and nonlinear measurements of the Tris(2',2-bipyridyl)iron(II) tetrafluoroborate. Optics Laser Tech. 2020, 131, 106449. [CrossRef]

12. Cornu, L.; Gaudon, M.; Jubera, V. $\mathrm{ZnAl}_{2} \mathrm{O}_{4}$ as a potential sensor: Variation of luminescence with thermal history. J. Mater. Chem. C 2013, 34, 5419. [CrossRef]

13. Pardo, E.; Train, C.; Liu, H.; Chamoreau, L.M. Multiferroics by Rational Design: Implementing Ferroelectricity in Molecule-Based Magnets. Angew. Chem. Int. Ed. Engl. 2012, 51, 8356. [CrossRef] [PubMed]

14. Xiang, Z.; Han, W.; Deng, J.; Zhu, W.; Zhang, Y.; Wang, H. Photocatalytic conversion of lignin into chemicals and fuels. ChemSusChem 2020, 13, 1.

15. Iao, K.; Hagiwara, H.; Yokoyama, C. Acidic ionic liquid modified silica gel as novel solid catalysts for esterification and nitration reactions. J. Mol. Catal. A Chem. 2006, 246, 65.

16. Wiscons, A.; Zeller, M.; Rowsell, J.L.C. Anion Exchange in Cationic Frameworks: Structures of Channel-Forming Triarylpyrylium Tetrafluoroborate Salts. Cryst. Growth Des. 2016, 16, 4. [CrossRef]

17. Enayati, M.; Faghihian, H. N-butyl-pyridinium tetrafluoroborate as a highly efficient ionic liquid for removal of dibenzothiophene from organic solutions. J. Fuel Chem. Technol. 2015, 43, 195. [CrossRef]

18. Fleck, M.; Petrosyan, A.M. Salts of Amino Acids: Crystallization, Structure and Properties; Springer: Dordrecht, The Netherlands, 2014; p. 574.

19. Liu, H.-X.; Liang, Y.-X.; Jiang, X. Synthesis, crystal structure and NLO property of a nonmetal pentaborate $\left[\mathrm{C}_{6} \mathrm{H}_{13} \mathrm{~N}_{2}\right]\left[\mathrm{B}_{5} \mathrm{O}_{6}(\mathrm{OH})_{4}\right]$. J. Solid State Chem. 2008, 181, 3243. [CrossRef]

20. Guieu, V.; Payrastre, C.; Madaule, Y.; Garcia-Alonso, S.; Lacroix, P.G.; Nakatani, K. Large Quadratic Nonlinear Optical Efficiencies in Pseudosymmetric Streptocyanine Dyes. Chem. Mater. 2006, 18, 3674. [CrossRef]

21. Ramajothi, J.; Dhanuskodi, S. Large Quadratic Nonlinear Optical Efficiencies in Pseudosymmetric Streptocyanine Dyes. Cryst. Res. Technol. 2003, 38, 986.

22. Rogers, R.D.; Seddon, K.R.; Volkov, S. (Eds.) Green Industrial Applications of Ionic Liquids; NATO Science Series; Springer Science \& Business Media: Berlin/Heidelberg, Germany, 2000.

23. Wasserscheid, P.; Welton, T. (Eds.) Ionic Liquids in Synthesis; Wiley VCH: Weinheim, Germany, 2002. 
24. Umebayashi, Y.; Mitsugi, T.; Fukuda, S.; Fujimori, T.; Fujii, K.; Kanzaki, R.; Takeuchi, M.; Ishiguro, S. Lithium Ion Solvation in Room-Temperature Ionic Liquids Involving Bis(trifluoromethanesulfonyl) Imide Anion Studied by Raman Spectroscopy and DFT Calculations. J. Phys. Chem. B 2007, 111, 13028. [CrossRef]

25. Sheldrick, M. "SHELXS-97", a Program for Automatic Solution of Crystal Structures, Release 97-2; Göttingen University: Göttingen, Germany, 1997.

26. Sheldrick, M. “SHELXL-97”, Program for the Refinement of Crystal Structures; University of Göttingen: Göttingen, Germany, 1997; Available online: https://www.scienceopen.com/document?vid=527f1309-ef7d-4d71-9985641965ab49ab (accessed on 13 September 2020).

27. Farrugia, J. WinGX suite for small-molecule single-crystal crystallography. J. Appl. Cryst. 1999, $32,837$. [CrossRef]

28. Shannon, D. Revised effective ionic radii and systematic studies of interatomic distances in halides and chalcogenides. Acta Crystallogr. A 1976, 32, 751. [CrossRef]

29. Johnson, C.K.; Burnett, M.N. ORTEP-III Version 1.0.2.: Oak Ridge, Thermal Ellipsoid Plot Program for Crystal Structure Illustrations, Oak Ridge National Laboratory Report ORNL-6895, USA 1996. Available online: https://digital.library.unt.edu/ark:/67531/metadc678816/ (accessed on 13 September 2020).

30. Ali, A.B.; Grenèche, J.-M.; Leblanc, M.; Maisonneuve, V. $\left[\mathrm{H}_{3} \text { tren }\right]^{3+}$ templated iron fluorides; synthesis, crystal structures and Mössbauer studies. Solid State Sci. 2009, 9, 1631. [CrossRef]

31. Adil, K.; Saada, M.A.; Ali, A.B.; Body, M.; Dang, M.T.; Hémon-Ribaud, A.; Leblanc, M.; Maisonneuve, V. Hydrogen bonded $\mathrm{H}_{3} \mathrm{O}^{+}, \mathrm{H}_{2} \mathrm{O}, \mathrm{HF}, \mathrm{F}^{-}$in fluoride metalates $(\mathrm{Al}, \mathrm{Cr}, \mathrm{Fe}, \mathrm{Zr}$, Ta) templated with tren (tris-(2-aminoethyl)amine). J. Fluor. Chem. 2007, 128, 404. [CrossRef]

32. Adil, K.; Ali, A.B.; Dujardin, G.; Dhal, R.; Leblanc, M.; Maisonneuve, V. Ternary and tetrahedral symmetry in hybrid fluorides, fluoride carbonates and carbonates. J. Fluor. Chem. 2004, 125, 1709. [CrossRef]

33. Stuart, B. (Ed.) Infrared Spectroscopy: Fundamentals and Applications; Wiley and Sons: Hoboken, NJ, USA, 2004; p. 104.

34. Abdi, I.; Alzahrany, F.; Lhoste, J.; Greneche, J.-M.; Ben Ali, A. Synthesis, crystal structure and Mössbauer study of new iron fluoride $\left[\mathrm{C}_{2} \mathrm{~N}_{5} \mathrm{H}_{6}\right] 2 \bullet\left(\mathrm{FeF}_{5}\left(\mathrm{H}_{2} \mathrm{O}\right) 2 \mathrm{H}_{2} \mathrm{O}\right.$. J. Adv. Chem. 2014, 10, 2617.

35. Chang, C.; Jiang, J.-C.; Liou, Y.-C.; Hung, C.-H.; Lai, T.-Y.; Lin, S.H. Local Structures of Water in 1-Butyl-3-methylimidazolium Tetrafluoroborate Probed by High-Pressure Infrared Spectroscopy. Anal. Sci. 2008, 24, 1305. [CrossRef] [PubMed]

36. Nakamoto, K. (Ed.) Infrared and Raman Spectra of Inorganic and Coordination Compounds; John Wiley and Sons: Hoboken, NJ, USA, 2009; p. 196.

37. Sukiasyan, P.; Suponitsky, K.Y.; Atanesyan, A.K.; Danghyan, A.A.; Hovhannisyan, A.A.; Petrosyan, A.M. Crystal structures and vibrational spectra of $\boldsymbol{L}$-argininium(2+) bis(tetrafluoroborate) and $\boldsymbol{L}$-argininium(2+) bis(perchlorate). Spectrochim. Acta A 2020, 228, 117782. [CrossRef] [PubMed] 